Article

\title{
Land Subsidence and Ground Fissures in Beijing Capital International Airport (BCIA): Evidence from Quasi-PS InSAR Analysis
}

\author{
Mingliang Gao $1,2,3,4,5, *$, Huili Gong $2,3,4,5$, Xiaojuan Li ${ }^{2,3,4,5}$, Beibei Chen ${ }^{2,3,4,5}$, \\ Chaofan Zhou ${ }^{1,2,3,4,5}$, Min Shi ${ }^{2,4,5}$, Lin Guo ${ }^{2,4,5} \mathbb{D}_{\text {, Zheng Chen }}{ }^{\text {, Zhongyun Ni }}{ }^{3,7}$ \\ and Guangyao Duan ${ }^{3,8}$ \\ 1 Beijing Advanced Innovation Center for Imaging Theory and Technology, Capital Normal University, \\ Beijing 100048, China; B328@cnu.edu.cn \\ 2 Base of the State Key Laboratory of Urban Environmental Process and Digital Modeling, Capital Normal \\ University, Beijing 100048, China; 4039@cnu.edu.cn (H.G.); 5099@cnu.edu.cn (X.L.); 6183@cnu.edu.cn (B.C.); \\ 2173601009@cnu.edu.cn (M.S.); 6382@cnu.edu.cn (L.G.) \\ 3 College of Resources Environment and Tourism, Capital Normal University, Beijing 100048, China; \\ nizhongyun2012@mail.cdut.edu.cn (Z.N.); duangy@tcu.edu.cn (G.D.) \\ 4 College of Geospatial Information Science and Technology, Capital Normal University, Beijing 100048, China \\ 5 Beijing Laboratory of Water Resources Security, Capital Normal University, Beijing 100048, China \\ 6 Chinese Research Academy of Environmental Sciences, Beijing 100012, China; zhengchen@mail.bnu.edu.cn \\ 7 College of Tourism and Urban-Rural Planning, Chengdu University of Technology, Chengdu 610059, China \\ 8 School of Geology and Geomatics, Tianjin Chengjian University, Tianjin 300384, China \\ * Correspondence: B312@cnu.edu.cn
}

Received: 20 May 2019; Accepted: 13 June 2019; Published: 20 June 2019

check for updates

\begin{abstract}
Land subsidence is a global environmental geological hazard caused by natural or human activities. The high spatial resolution and continuous time coverage of interferometric synthetic aperture radar (InSAR) time series analysis techniques provide data and a basis for the development of methods for the investigation and evolution mechanism study of regional land subsidence. Beijing, the capital city of China, has suffered from land subsidence for decades since it was first recorded in the 1950s. It was reported that uneven ground subsidence and fractures have seriously affected the normal operation of the Beijing Capital International Airport (BCIA) in recent years before the overhaul of the middle runway in April 2017. In this study, InSAR time series analysis was successfully used to detect the uneven local subsidence and ground fissure activity that has been gradually increasing in BCIA since 2010. A multi-temporal InSAR (MT-InSAR) technique was performed on 63 TerraSAR-X/TanDem-X (TSX/TDX) images acquired between 2010 and 2017, then deformation rate maps and time series for the airport area were generated. Comparisons of deformation rate and displacement time series from InSAR and ground-leveling were carried out in order to evaluate the accuracy of the InSAR-derived measurements. After an integrated analysis of the distribution characteristics of land subsidence, previous research results, and geological data was carried out, we found and located an active ground fissure. Then main cause of the ground fissures was preliminarily discussed. Finally, it can be conducted that InSAR technology can be used to identify and monitor geological processes, such as land subsidence and ground fissure activities, and can provide a scientific approach to better explore and study the cause and formation mechanism of regional subsidence and ground fissures.
\end{abstract}

Keywords: ground settlement; MT-InSAR; quaternary sediment thickness; groundwater; runways 


\section{Introduction}

Land subsidence occurs in over 150 countries all over the world, particularly in densely populated metropolitan areas, such as big cities in China [1-3], Japan [4], Italy [5], Mexico [6,7], and Indonesia [8,9], with extremely serious consequences. Beijing, one of the largest cities in the world, has suffered from land subsidence since the 1950s [10]. According to public reports from the China Geological Survey (CGS), the area with a sinking rate of $>50 \mathrm{~mm} /$ year in Beijing plain was over $770 \mathrm{~km}^{2}$ in 2017, with a maximum sinking rate of $157 \mathrm{~mm} /$ year, and the maximum cumulative subsidence in Beijing Plain reached $1864 \mathrm{~mm}$ in 2017. Differential land subsidence can result in ground fissures and can lead to damage to buildings, dams, roads, high-speed railways, airports [11] and other urban facilities (e.g., pipelines, flyovers, subway lines, and underground structures).

Beijing Capital International Airport (BCIA) is located in Shunyi District, northeast of downtown Beijing, and the airport's platform has been experiencing land subsidence since 2003 [12]. In particular, uneven land subsidence occurred in the northern area of the BCIA in recent years [13,14], which has seriously affected the safe operation of the airport. The airport handled more than 1700 flights and 270,000 passengers per day in 2017. Geological hazard such as land subsidence and ground fissure in an airport can lead to damage of ground facilities such as terminals, runways, and electronic equipment and can cause personal security and economic losses [11]. Therefore, monitoring the temporal and spatial evolution of long-term land subsidence is critical to implementing disaster warnings and remedial measures for such critical civil infrastructure to minimize potential damage. Considering the potential damage that ground fissures can cause to the environment, numerous techniques (e.g., geodetic survey and geophysical exploration technology) have been used to monitor and study the formation mechanism of ground fissures [15-17]. Geodetic methods, such as leveling and global positioning systems (GPS), tend to focus on deformation monitoring of ground fissures, while geophysical methods are commonly used to detect the location and depth of underground fractures.

Over the past few decades, interferometric synthetic aperture radar (InSAR) has been developed as an effective geodetic surveying technique and used for investigating geophysical phenomena, including seismic deformation [18,19], volcano dynamics [20,21], earthquakes [22,23], landslides [24,25], and other geologic processes. The InSAR technique can also monitor the ground deformation caused by human activities (e.g., mining [26,27], delta sinking [28], and land subsidence [29-32]). Ground fissure is commonly a secondary environmental geological problem caused by land subsidence [33] and the InSAR technique can provide a new tool for investigating ground fissure activity [34,35]. Compared with the conventional ground-based measurement methods on sparse points, such as differential GPS and leveling, InSAR can determine a planar observation on a large scale with high precision and low cost [30]. Since the revisit period of the space-borne radar system is currently less than two weeks (e.g., for TerraSAR-X/TanDEM-X and Sentinel-1A/1B, the orbit recurrent period can be shortened to 11 and 6 days, respectively), this technique can also provide sufficient data for long-term observations. However, the conventional InSAR technique is fatally limited by temporal and spatial decorrelation and atmospheric delay caused by different satellite positions, long acquisition intervals, and atmospheric fluctuations [36], respectively. In this case, the deformation monitoring accuracy provided by D-InSAR is only from decimeters to centimeters and there are still great limitations in the application of urban infrastructure monitoring. Hence, persistent scatterer interferometry (PS-InSAR) $[37,38]$ has been developed to overcome the incoherence limitation over time intervals and large areas of the conventional InSAR technique. This advanced technique represents a specific class of multi-temporal InSAR (MT-InSAR) techniques, which allows us to restore the process of ground deformation at millimeter accuracy level by identifying the target points with stable scattering characteristics (PS points) from multiple synthetic aperture radar (SAR) images of the same area during the SAR acquisitions $[39,40]$. The PS-InSAR technique has obvious advantages in urban land subsidence monitoring, since buildings and artificial facilities provide high-density PS points and greatly improve the signal to noise ratio (SNR) of the interferograms. 
The purpose of this paper is to provide a better identification and understanding of local subsidence and ground fracture activity in the airport area by using MT-InSAR technique. In this paper, long-term land subsidence at BCIA, Beijng, was obtained by performing an advanced multi-temporal InSAR approach. The dataset consists of 63 TSX/TDX scenes from April 2010 to December 2017. This study has two main purposes. Firstly, an advanced PS-InSAR approach-Quasi-PS InSAR (QPS-InSAR) [41]—was applied to investigate the ground deformation of the BCIA, then extra leveling data was used to evaluate the accuracy of the InSAR-derived measurements. Finally, the characteristic of the newly discovered ground fissures was described and an integrated analysis of hydrogeological data and InSAR-derived measurements was carried out to discuss the main cause of the ground fissures.

\section{Study Site}

Beijing, located in the north of China mainland, covers a region of between $39.4^{\circ} \mathrm{N} 115.7^{\circ} \mathrm{E}$ and $41.6^{\circ} \mathrm{N} 117.4^{\circ} \mathrm{E}$, with a total area of over $16,000 \mathrm{~km}^{2}$ and a population of 21.542 million (2018). The west, north, and northeast of the city are surrounded by mountains and the southeast is a plain (named Beijing Plain) toward the Bohai sea. The Beijing Plain, with elevation of between 20 and $40 \mathrm{~m}$, is a typical piedmont alluvial diluvial plain formed from sediments carried by the Yongding, Chaobai, and Wenyu rivers. Beijing has a typical warm temperate semi-humid continental monsoon climate, with four distinct seasons; the annual average temperature is approximately $10-12{ }^{\circ} \mathrm{C}$ and the mean annual precipitation is about $600 \mathrm{~mm}$ (from 1949 to 2018).

Beijing currently has three civil airports, namely the Beijing Capital International Airport, Nanyuan Airport, and the recently completed Daxing International Airport. The BCIA is located in the northeast of Beijing, $25 \mathrm{~km}$ from downtown (Figure 1a). The airport was built in 1958 and has been in operation for more than 60 years. As shown in Figure 1b, which covers an area of $14.8 \mathrm{~km}^{2}$, the airport has three terminals (namely T1, T2, and T3, respectively), three runways (01/19, 18L/36R, and 18R/36L; detailed information is shown in Table 1), and 314 aircraft stands. In 2018, the airport handled a total of 614,022 air traffic movements, 100,983,290 passengers, and over 2,074,000 tons of cargo, representing year-on-year decreases of $2.8 \%, 5.4 \%$, and $2.2 \%$, respectively (statistics were provided by the civil aviation administration of China).

The continuous over-exploitation of groundwater in Beijing Plain has resulted in two main subsidence zones - the northern zone and southern zone. The northern subsidence zone caused by groundwater withdrawal includes several sinking centers (Figure 1a), such as Laiguangying and Balizhuang-dajiaoting in Chaoyang funnel, Nanfaxin in Shunyi funnel, Liyuan-taihu in Tongzhou funnel, and Shahe-baxianzhuang in Changping funnel. The BCIA is located nearby the Nanfaxin sinking center. The airport has a history of land subsidence problems and has been studied in detail [13].

Table 1. The detailed information of runways in BCIA.

\begin{tabular}{cccc}
\hline Designations RWY NR & GEO BRG $\left(^{\circ}\right)$ & MAG BRG $\left(^{\circ}\right)$ & Dimensions of RWY (m) \\
\hline 01 & 353 & 359 & $3800 \times 60$ \\
19 & 173 & 179 & $3800 \times 60$ \\
$18 \mathrm{~L}$ & 173 & 179 & $3800 \times 60$ \\
36R & 353 & 359 & $3800 \times 60$ \\
18R & 173 & 179 & $3200 \times 50$ \\
36L & 353 & 359 & $3200 \times 50$
\end{tabular}

RWY and NR are the abbreviations for runway and number. GEO BRG and MAG BRG are the abbreviations for geographic bearing and magnetic bearing, respectively. 


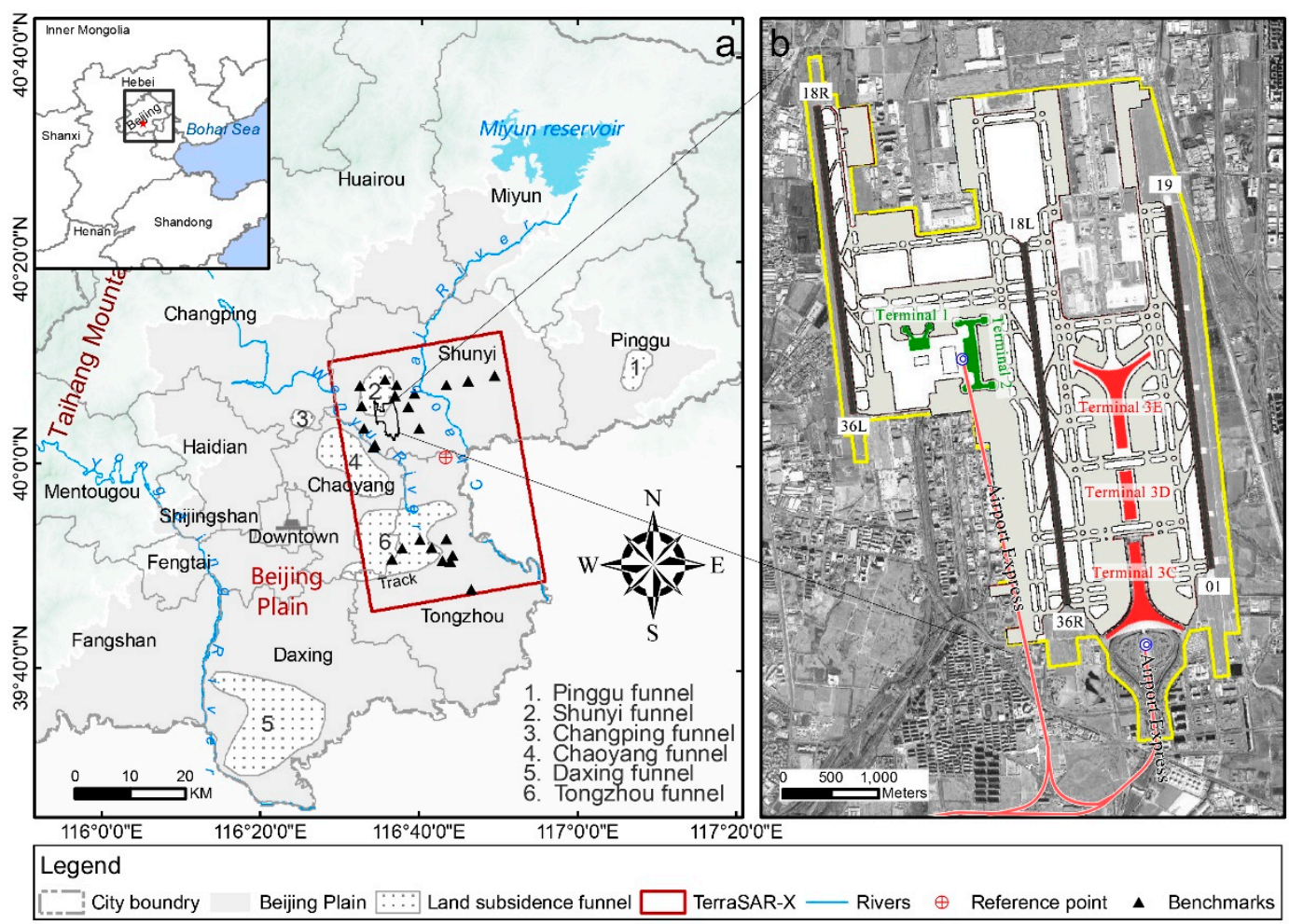

Figure 1. (a) The location of the study site and (b) a sketch map of the Beijing Capital International Airport (BCIA). The inset on the top left shows the base map of Beijing. The red rectangular represents the frame of the used TerraSAR-X data. The black triangles indicate the benchmarks used in this study. The black outline indicates the airport boundary. The red circle with the cross indicates the location of the reference point. The digits indicate the six sinking centers. The red lines and blue circles represent the airport express and stations, respectively.

Figure 2 is the distribution map of the quaternary sediments (QS) and major faults, superimposed with compressible thickness (CT) contours and recorded epicenters around the study site. The quaternary sediments with good compressibility near the study area are about 150-250 m thick, which was proved to provide geological conditions for the generation and development of local land subsidence [42]. The Shunyi-liangxiang fault is one of the major faults crossing the study area, with a total length of $35 \mathrm{~km}$ and a trend of $\sim 30-40 \mathrm{NE}$. According to the geological survey report of Shunyi county, the Shunyi-liangxiang fault runs through the whole quaternary period stratum and the staggered distance decreases successively from the bottom to the top. The fractured surface of the Shunyi-liangxiang fault extends to the ground and there is an obvious offset at a depth of $5 \mathrm{~m}$, with a maximum vertical dislocation of $14 \mathrm{~cm}$. Also, the early activity of Shunyi-liangxiang faults resulted in an obvious difference in thickness between the upper side (NW) and the lower side (SE), about $300 \mathrm{~m}$, and uneven soil structure on both sides of the fault. 


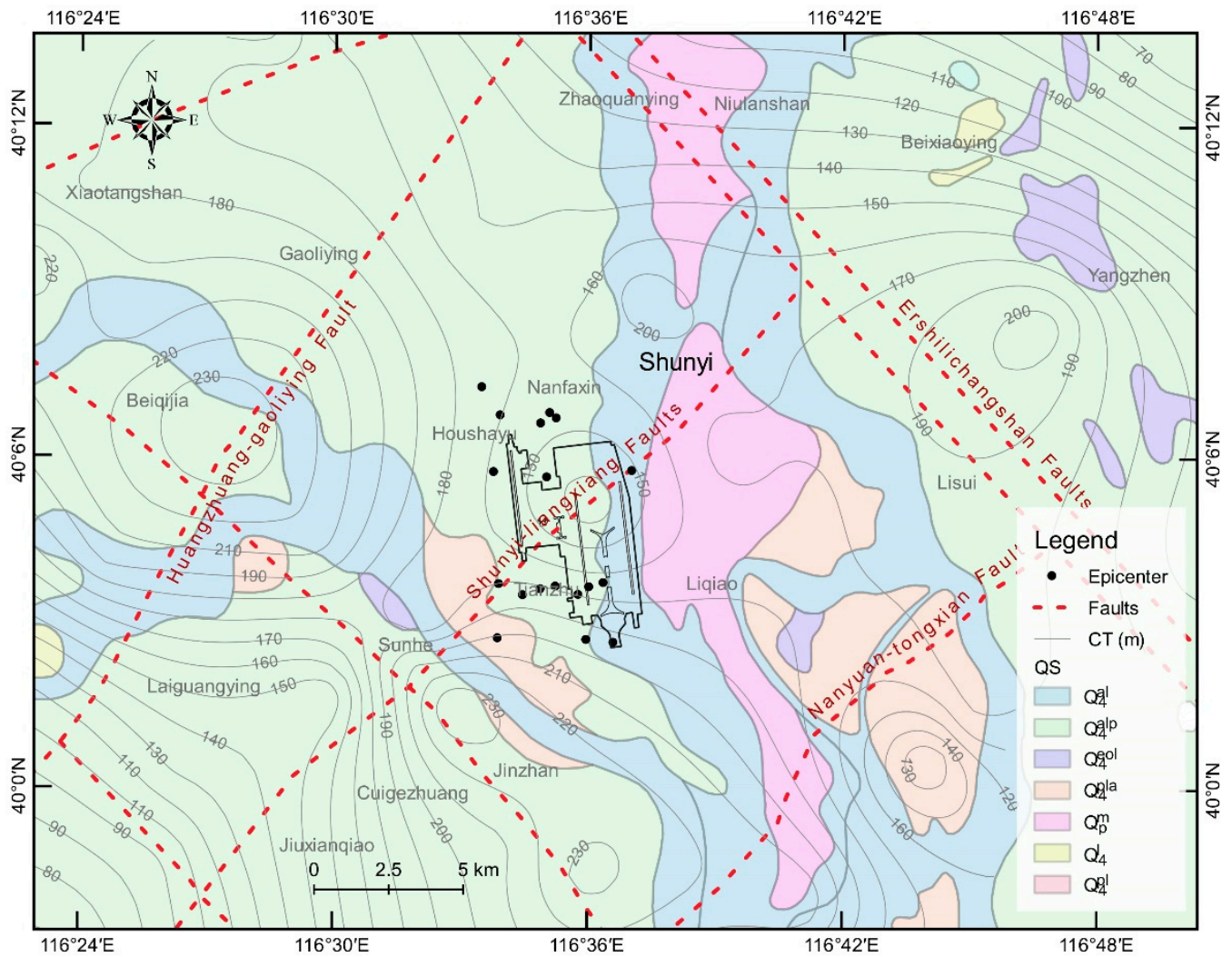

Figure 2. The distribution map of the quaternary sedimentary types and major faults around BCIA, Shunyi County. The red dash line represents the direction of the fault. The black points indicate the locations of minor earthquake epicenters recorded near the BCIA. The black outline indicates the airport boundary. The gray contour with digitals represents the thickness of the compressible layer. The $Q_{4}^{a l}, Q_{4}^{a l p}, Q_{4}^{e o l}, Q_{4}^{\text {pla }}, Q_{\mathrm{p}}^{m}, Q_{4}^{l}$, and $Q_{4}^{p l}$ indicate the quaternary alluvium sediments, the quaternary alluvial-diluvial sediments, the quaternary eolian sediment, the quaternary diluvial-alluvium sediments, the quaternary marine sediments, the quaternary lacustrine sediment, and the quaternary diluvial sediment, respectively.

\section{Materials and Methods}

\subsection{SAR Data Set and Elevation Data}

In this study, 63 TerraSAR-X/TanDem-X (TSX/TDX) SAR images in stripmap mode was collected between April 2010 and December 2017 from ascending orbit, with $\mathrm{HH}$ polarization. The spatial resolution of the TSX/TDX stripmap mode image is better than $3 \mathrm{~m}$ on the ground, which is more suitable for identifying permanent scatterers (PS) in urban areas. The external digital elevation model (DEM) used for MT-InSAR processing to remove the topographic phase and flatten effects was obtained from the TerraSAR-X add-on for Digital Elevation Measurements. The open downloaded TanDEM-X $90 \mathrm{~m}$ DEM is a product derived from the global DEM with a 0.4 arcsec posting, with an absolute vertical accuracy of $10 \mathrm{~m}$ and an relative vertical accuracy of $2 \mathrm{~m}$, which is better than that of SRTM DEM (more information is available at: https://geoservice.dlr.de/web/dataguide/tdm90/).

As shown in Figure 3, the TSX/TDX dataset has perpendicular baselines ranging from -178.8 to $297.9 \mathrm{~m}$ and temporal baselines ranging from 44 to 1573 days, with respect to the master image dated 2014/08/14. 


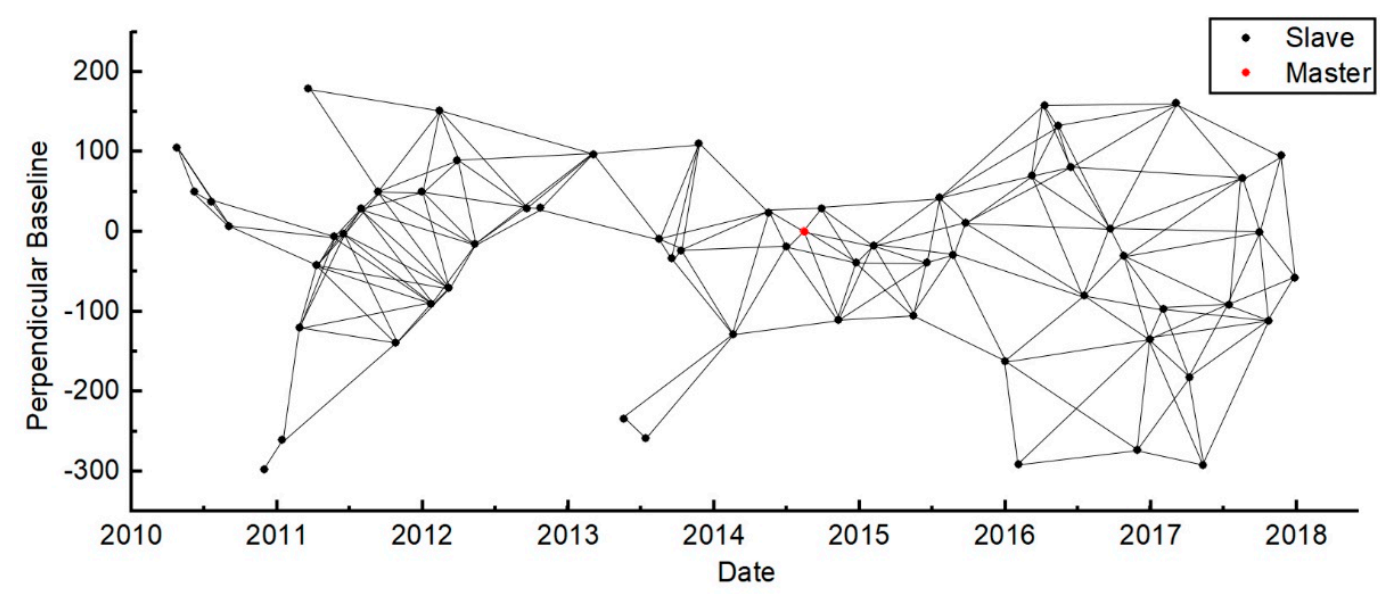

Figure 3. The spatial and temporal baseline distribution and interferogram pairs used in this paper. All the SAR images were spatially registered to the master image acquired on 14 August 2014.

\subsection{MT-InSAR Processing}

The Quasi-PS technique is an advanced PS-InSAR approach, which is able to extract information of partially coherent targets as the weight of phase estimation [43]. Since the specific information carried by interferograms can be different from point to point, the coherent interferograms subset of each point must be considered [44]. Hence, in QPS-InSAR processing, only the appropriate target-dependent subset of interferograms is used to estimate the target height and displacement. In this study, the quasi-PS processing was carried out using the SARPROZ software (refer to https://www.sarproz.com/). Within the standard single master PS-InSAR processing in SARPROZ, the master scene for co-registration was selected by synthetically taking into account space-time baselines, Doppler centroid frequency different, and the weather information (such as precipitation, temperature, atmospheric pressure, humidity, and cloud cover) at the time of the SAR image acquisition, to minimize the decorrelations of the single master interferograms. After co-registration, the external DEM was imported and a series of interferograms were generated by InSAR processing. Following this, persistent scatterer candidates (PSCs) were chosen by applying a threshold on the amplitude stability index (ASI) for the first time. An atmospheric phase screen (APS) was then estimated and removed the base on a given reference point. Finally, relative height, absolute height, displacement, and deformation rate were collectively estimated from the filtered interferogram subset and TS (time series) deformation was reconstructed simultaneously.

Afterward, only PS points with high temporal coherence (better than 0.75 in this study) were selected for further analysis, to ensure a high coherence and stability within the SAR-image acquisition time-span. Since previous studies pointed out that Beijing Plain presented a low horizontal movement of $1.57-1.93 \mathrm{~mm} /$ year $[45,46]$ and vertical displacement is a prerequisite for the comparison with ground-leveling measurements, the displacement from line-of-sight (LOS) was converted to vertical by using Equation (1):

$$
d_{v}=\frac{d_{L O S}}{\cos \theta}
$$

where $d_{v}$ is the vertical displacement (mm), $d_{L O S}$ is the line-of-sight (LOS) displacement (mm), and $\theta$ is the incidence angle ( $35.28^{\circ}$ for TSX/TDX stripmap mode in this study). 


\subsection{Measurement Calibration}

The InSAR technique measures the movement relative to the reference point, so it is crucial to select a stable point as the reference point to estimate the displacement and deformation rate. During QPS processing, points meeting the following requirements can be selected as a reference point: The peak of residual height histogram should be at value 0 , which indicates the reference point is on the ground and the peak of estimated velocity histogram should also be at value 0 , which indicates the reference point is relatively stable.

The reference point of the QPS-InSAR analysis in this study was set near Xuxinzhuang in Tongzhou District (Figure 1a), corresponding to a PS point with a high ASI value (0.98). Since the absolute deformation of the reference point was unknown, the InSAR measurement was calibrated by utilizing the observation records provided by the subsidence monitoring station located in the subsidence center of Pinggezhuang. Unfortunately, the location of the station did not correspond to any PS points, hence the average measurement of the radar targets located within a distance of $100 \mathrm{~m}$ from the monitoring station was used instead. Then, the displacement time series of each PS points were updated accordingly using Equation (2). The calibration factor $v_{\text {diff }}$ has been quantified as $-4.2 \mathrm{~mm} /$ year in this study.

$$
d\left(t_{i}\right)=d_{\text {insar }}\left(t_{i}\right)-v_{\text {diff }} \cdot \Delta t,
$$

where $d\left(t_{i}\right)$ is the corrected displacement at the time, $t_{i} d_{\text {insar }}$ is the InSAR-derived displacement at the time, $t_{i} v_{\text {diff }}$ is the calibration factor calculated from station observations, and $\Delta t=t_{i}-t_{0}$ is the time-span (in years) from the first (April 2010) to the $i$-th scene.

\section{Results}

\subsection{InSAR-derived Measurements}

By applying the QPS technique, a total of 389,515 PS points were identified from more than 180 interferograms (as shown in Figure 3), among which about 9000 PS points were located within the BCIA area, with a density of about 640 points $/ \mathrm{km}^{2}$. Figure 4 illustrates all the PS points detected by the QPS-InSAR approach, colored with the corresponding vertical displacement $(\mathrm{cm})$. The displacements were relative to a reference point in Figure 1a and calibrated by Equation (2). In this study, negative values in all the figures indicate downward movement of the ground, while positive values indicate uplift. Figure 4 shows the overall displacements of the whole coverage from the SAR data frame spanning 2010 to 2017, derived from TSX/TDX dataset by using the QPS technique. The results indicated that significant land subsidence occurred in the eastern Beijing Plain. The unevenness of the spatial distribution was also revealed by the InSAR-derived displacement map. The serious subsidence regions were mainly located in the southwest of Shunyi District, the east of Chaoyang District, and the north of Tongzhou District. In particular, the maximum displacement of $-117.4 \mathrm{~cm}$ and maximum sinking rate of $152.9 \mathrm{~mm} /$ year were both observed in Chaoyang funnel. In addition, it was noticed that multiple subsidence regions, such as the Chaoyang and Tongzhou funnels, joined together with large spatial coverage [47]. 


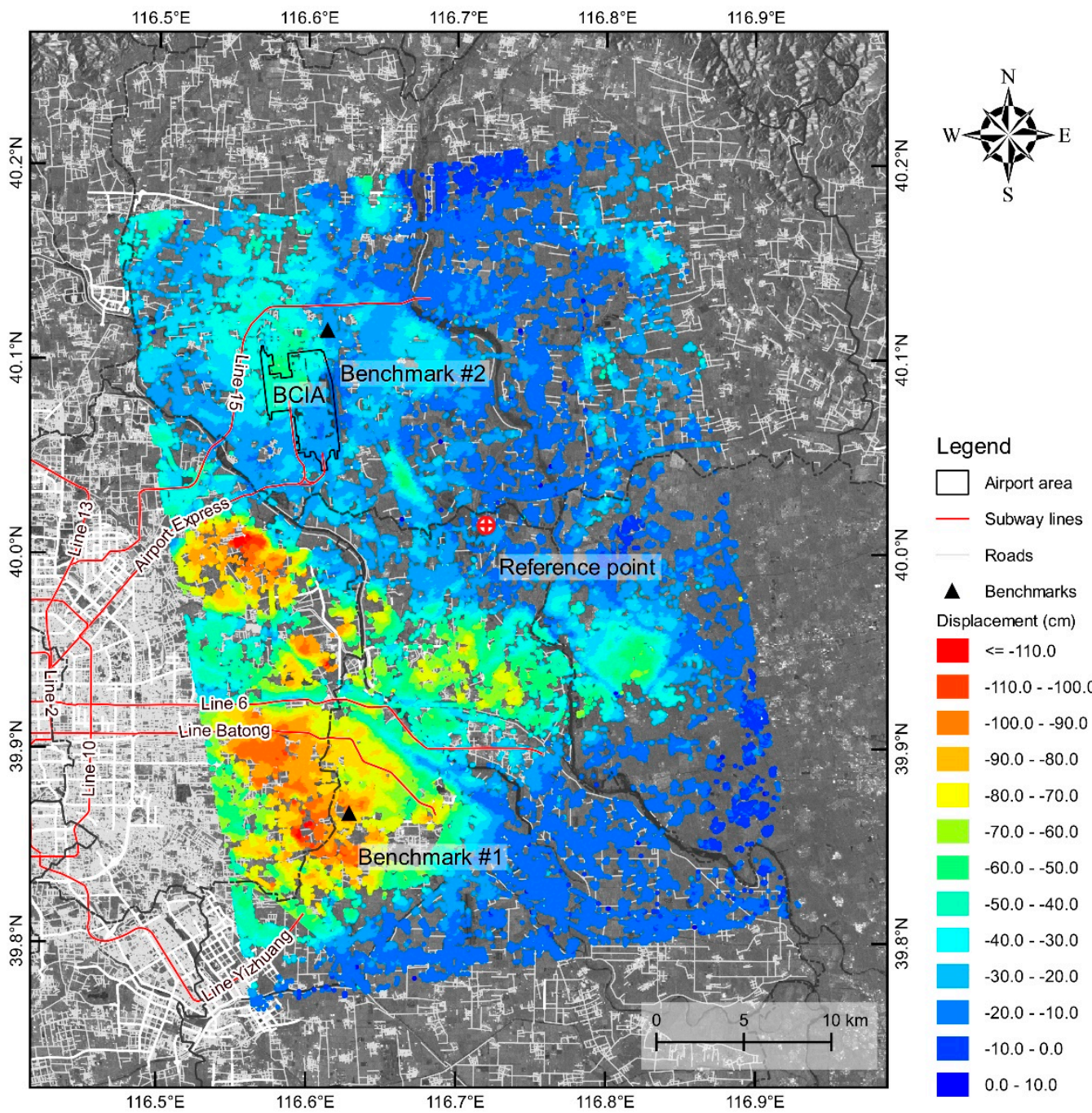

Figure 4. Vertical displacement map superimposed on synthetic aperture radar (SAR) reflectivity in the eastern Beijing Plain area. The red lines represent subway lines and the black triangles indicate the benchmarks used for comparison purposes in Figure 6.

In order to show the deformation pattern more clearly, we zoomed in and recolored partial details of the airport area. As shown in Figure 5, most of the PS points were identified on angular targets (e.g., buildings), but many of them were in areas without angular reflection structures, such as runways and platforms in the north of the airport. Predictably, various degrees of land subsidence were observed in the airport area and the figures showed that the land deformed at different rates during April 2010 to December 2017, between $-69.6 \mathrm{~mm} /$ year (sinking) and $+8.1 \mathrm{~mm} / \mathrm{year}$ (uplift). We drew a boundary, A- $\mathrm{A}^{\prime}$ (marked as the red dashed line in Figure 4), roughly to divide the region into two subregions with distinct subsidence characteristics, according to the distribution of the deformation rate. The northwest showed a clear trend of subsidence (e.g., 18R/36L and 18L/36R runway, terminal $\mathrm{T} 1$ and $\mathrm{T} 2$, and the Northern Airport Expressway), while the southwest showed little ground motion. However, the deformation rates generated from QPS-InSAR measurements also pointed out that, even at very short distances, there was relative spatial variability on the terminal T2 buildings and north $18 \mathrm{~L} / 36 \mathrm{R}$ runway. Details will be presented in the next section. 


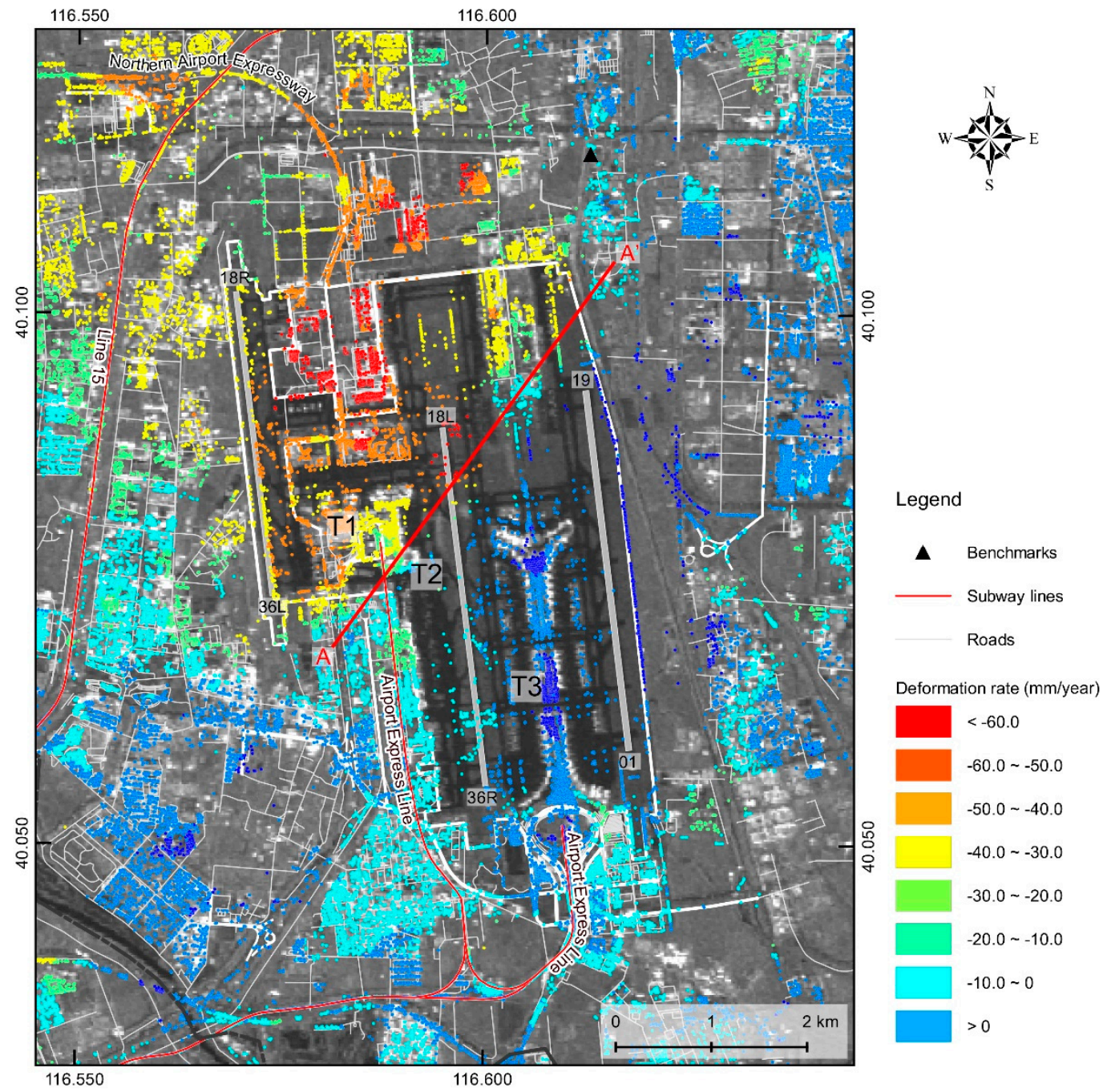

Figure 5. Vertical deformation rate map superimposed on SAR reflectivity in the BCIA area. A- $A^{\prime}$ is an imaginative boundary that divide the airport area into two subregions with distinct subsidence characteristics. The red lines represent subway lines.

\subsection{Validation With Ground Leveling Measurements}

The InSAR-derived observations in this study were compared with the ground-leveling measurements, including deformation rate and displacement time series, to verify the reliability of the results from QPS-InSAR processing. The averages of the measurements from pixels lying nearby (with a distance of less than $100 \mathrm{~m}$ ) each benchmark were calculated as the corresponding InSAR measurements by assuming that the ground did not change significantly within this distance. As shown in Figure 6, a cross-comparison was performed between InSAR and leveling measurements by linear regression analysis. The deformation rates from leveling and InSAR measurements show good agreement, with a correlation coefficient of 0.96 and a standard error of $1.33 \mathrm{~mm} /$ year.

To further validate our results, the InSAR-derived displacement time series were compared with ground-leveling measurements at the selected two benchmarks (marked by black triangles in Figure 3). Figure 7 compares the time series plots of measurements from the two leveling sites and InSAR. It can be observed that the displacement time series of the two methods are in good agreement. The root mean square (RMS) errors for InSAR measurements at benchmark \#1 and \#2 were $6.5 \mathrm{~mm}$ and $3.8 \mathrm{~mm}$, respectively. These comparisons suggest that the MT-InSAR technique is effective and reliable in extracting ground deformation information. In addition, since the observing frequency of leveling 
(in years) is much lower than that of the spaceborne SAR system (almost monthly), it is not possible to describe the deforming process in detail over the whole period.

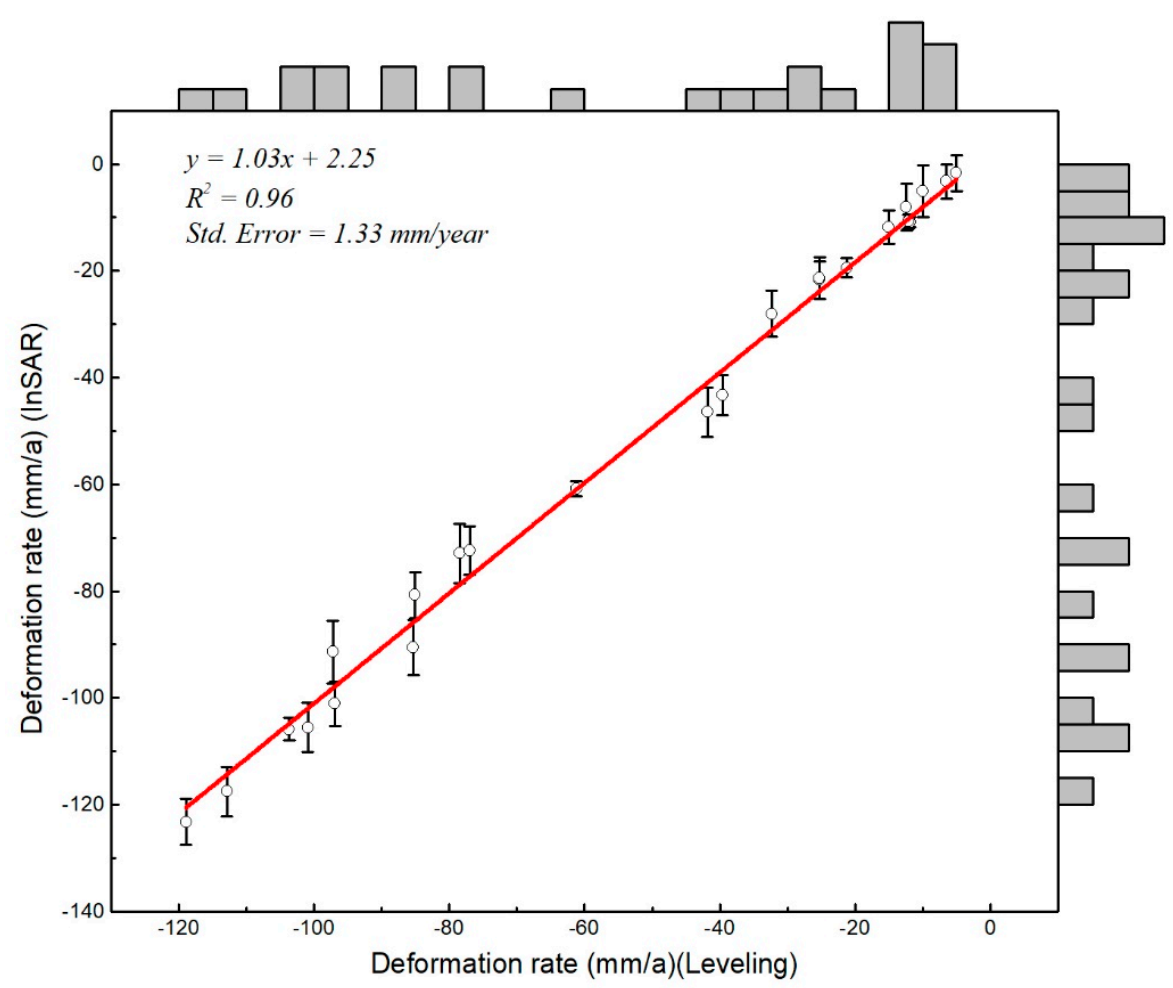

Figure 6. Comparison of interferometric synthetic aperture radar (InSAR) and ground-leveling-derived deformation rates at the 24 benchmarks during 2010-2017. The correlation coefficient is 0.96 with a standard deviation of $1.33 \mathrm{~mm} /$ year.

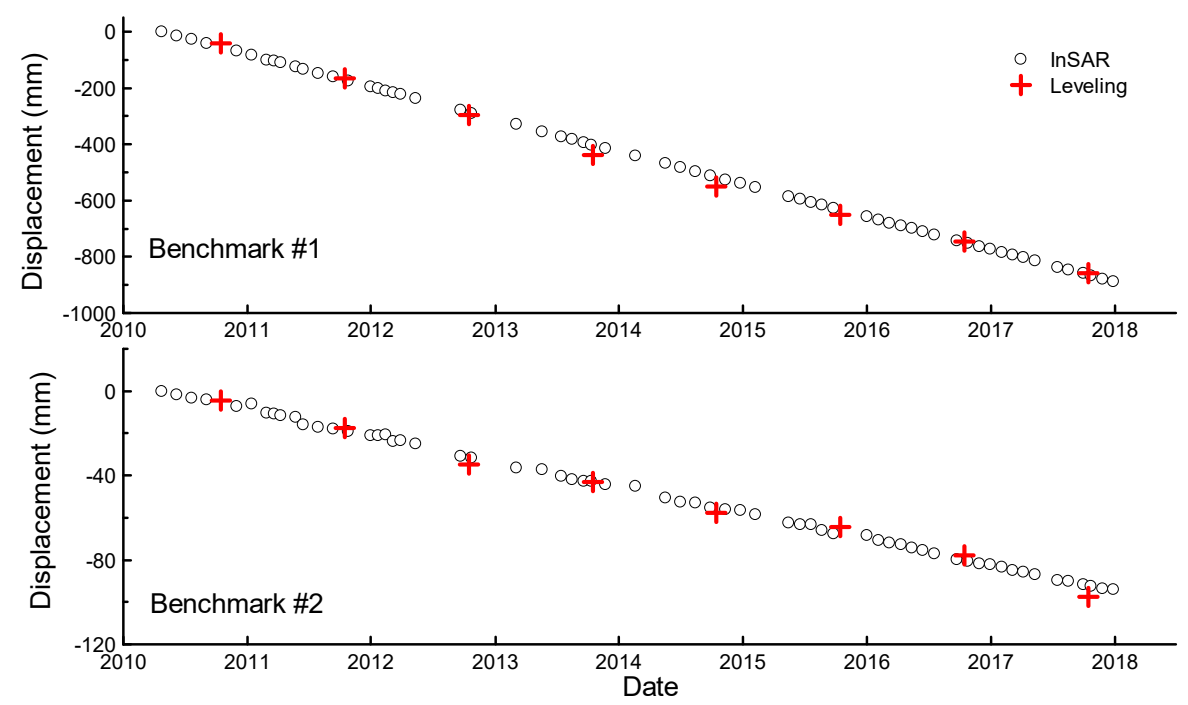

Figure 7. Comparison of the displacement time series measured by (InSAR) and ground-leveling at benchmarks \#1 and \#2.

\subsection{Ground Fissures Identified By InSAR}

As described above, the land subsidence in the capital airport area was obviously zoned and the deformation rates in the northwest and southeast regions are quite different. The uneven land subsidence in the airport area has lasted for several years and there will definitely be accumulation 
effect, e.g., damage to runways, buildings, and electric equipment. In order to ascertain whether the uneven ground deformation has affected the normal activities of the airport, we collected some relevant materials, including news articles, media reports, papers, and internal reports that cannot be made public. As reported, construction of the 18L/36R runway started in 1954 and was completed in 1958 and it has been used for more than 20 years since 1996 when asphalt concrete was added. In recent years, the differential land subsidence caused relative ground fluctuations within a short distance, which affects the safe operation of the aircraft when passing through. The runway was repaired partially in 2013 and 2015, but was completely overhauled in 2017. The 28-day complete overhaul in April 2017, involving an area of $200,000 \mathrm{~m}^{2}$, was partly aimed at repairing runway cracks and fluctuations caused by uneven subsidence. In the meantime, as field investigations show, the terminal T2 that was put into use at the end of 1999 also suffered from land subsidence and local ground fissures.

In order to locate the ground fissures from the InSAR-derived measurements, we calculated the gradient of land subsidence rate in the study area. Thus, the general location of the fracture was determined by profile analysis along the direction in which the InSAR-derived deformation rate changed the most. The analysis indicated that the ground fissures were distributed roughly along the $\sim 35-55^{\circ} \mathrm{N}$ direction. The primary direction of the ground fissures was identified as $43.1^{\circ} \mathrm{N}$ and is marked as the red dashed line in Figure 8.

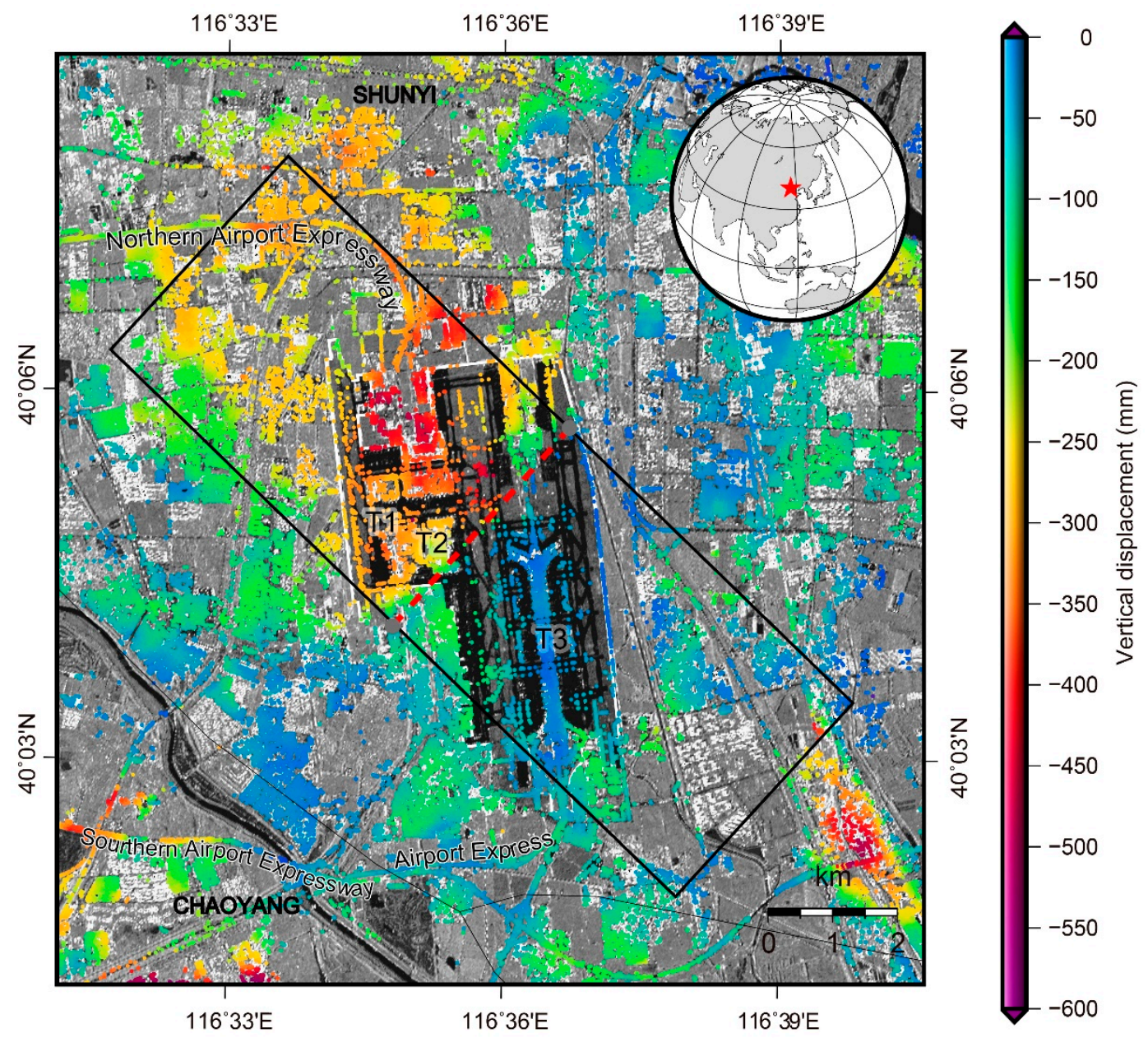

Figure 8. The distribution of the cumulative vertical displacement $(\mathrm{mm})$ derived from the time series InSAR approach in the study area between 2010 and 2017. The red dashed line indicates the location of the primary ground fissure identified by InSAR measurements. Data within the black box are shown in Figure 9 . 


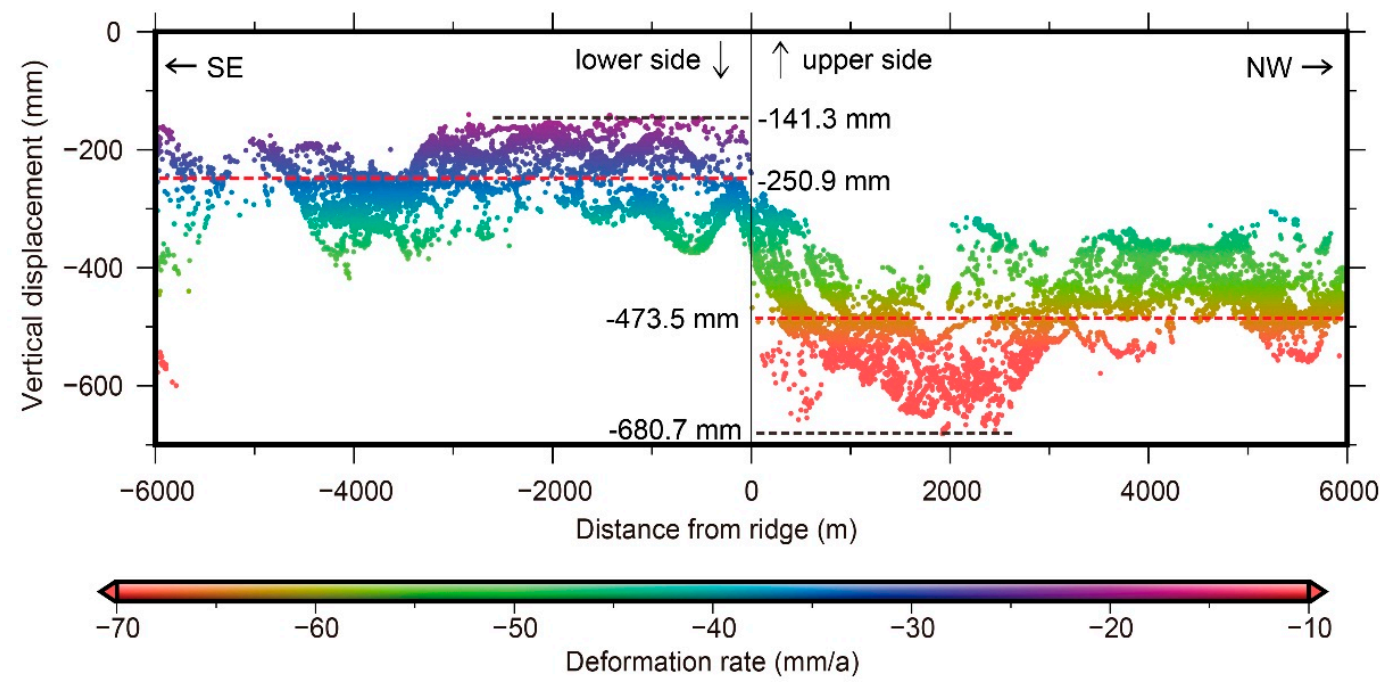

Figure 9. The profiles of InSAR vertical displacement from the points within the black box in Figure 8 , colored by deformation rate. The centerline indicates the location of the identified ground fissure (marked as the red dashed line in Figure 8). The dashed black lines indicate the maximum and minimum cumulative vertical displacement and the dashed red lines indicate the average vertical displacements on both sides of the ground fissure.

In this case, we took the segment (about $4 \mathrm{~km}$ ) where the ground fissure was located as the centerline (zero-scribed line in Figure 9) and extended the buffer zone of $6 \mathrm{~km}$ on both sides. Then, an area of about $12 \times 4 \mathrm{~km}^{2}$ was obtained (marked as the black box in Figure 8). We plotted the cumulative vertical displacement of the points within the black box onto a profile sketch and colored each point according to the deformation rate.

As shown in Figure 9, the minimum value of the vertical displacement from the points on the SE (lower) side of the ground fissure is $-141.3 \mathrm{~mm}$, with an average settlement of $250.9 \mathrm{~mm}$ and a sinking rate of $33.2 \mathrm{~mm} /$ year; the maximum value of the vertical displacement from the points on the NW (upper) side of the ground fissure is $-680.7 \mathrm{~mm}$, with an average settlement of $473.5 \mathrm{~mm}$ and a sinking rate of $61.7 \mathrm{~mm} /$ year. The maximum relative displacement on both sides of the ground fissure is over $530 \mathrm{~mm}$, while the difference in average settlement and sinking rate on both sides reach $222.6 \mathrm{~mm}$ and $28.5 \mathrm{~mm} /$ year, respectively.

The distribution characteristics of ground subsidence can more or less provide clues to the activity of the new ground fissures, especially after 2010, since runway 18L/36R has dropped more than 200 $\mathrm{mm}$ in the north relative to the sinking surface from 2003 to 2013, as shown in our previous study [13]. The differences between the sinking rate of points on both sides of the ground fissure have further increased. As illustrated in Figure 10, the sinking rate on the roof from the northern and southern waiting halls of terminal T2 were $37.6 \mathrm{~mm} /$ year (P1) and $7.1 \mathrm{~mm} / \mathrm{year}(\mathrm{P} 2)$, respectively. Even more than that, the InSAR-derived measurements showed the relative deformation rate of runway $18 \mathrm{~L} / 36 \mathrm{R}$ exceeded $47 \mathrm{~mm} /$ year, with a relative displacement of $365.4 \mathrm{~mm}$ during April 2010 to December 2017. The time series displacements and deformation rates of the selected P1, P2, P3, and P4 are listed on the right panel in Figure 10. Meanwhile, the activity of the newly identified ground fissure in the capital airport area is increasing and it requires constant attention. 

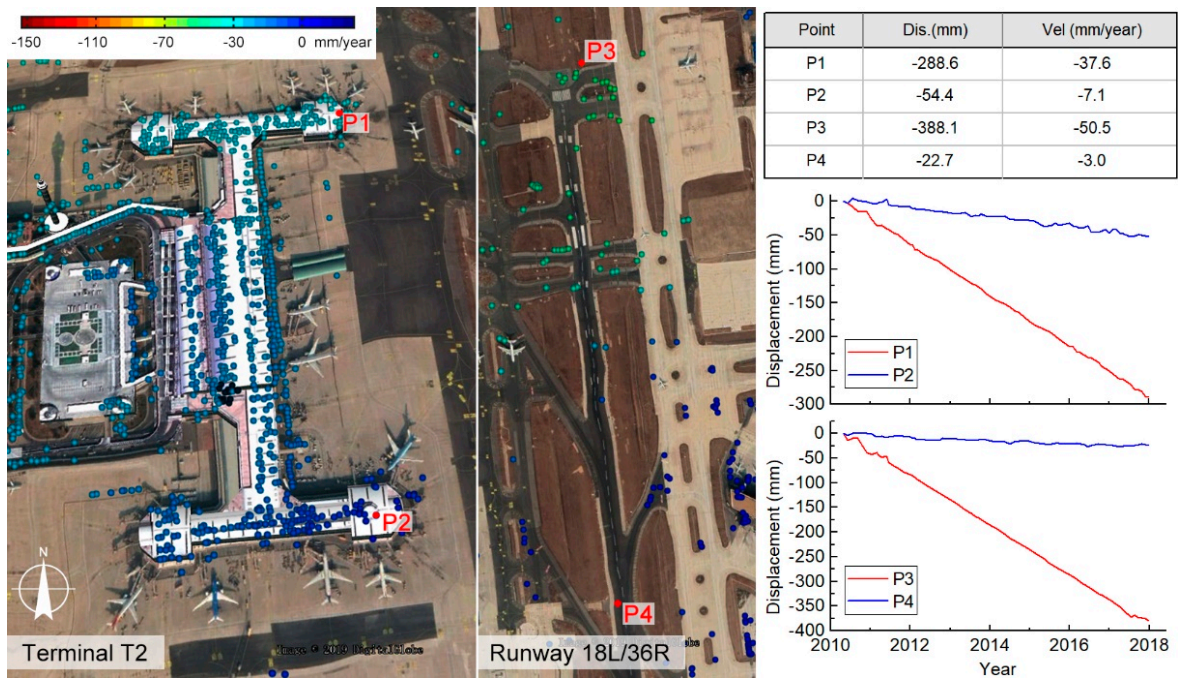

Figure 10. The locations of the selected points P1, P2, P3, and P4 and comparison of the time series displacement and subsidence velocity of each point on the right.

\section{Discussion}

As one of the busiest airports in the world, it is difficult to carry out underground detection or other related field work for the BCIA area. In this case, the cause of ground fissures can only be preliminarily discussed through limited hydrogeological data. In order to preliminarily analyze the genesis of ground fissures, we collected limited geological data and plotted them on the interpolated deformation rate map (Figure 11). As can be seen, the ground fissure is located in the southern section of the Shunyi-liangxiang faults and the strike of ground fissure is basically the similar as the active fault.

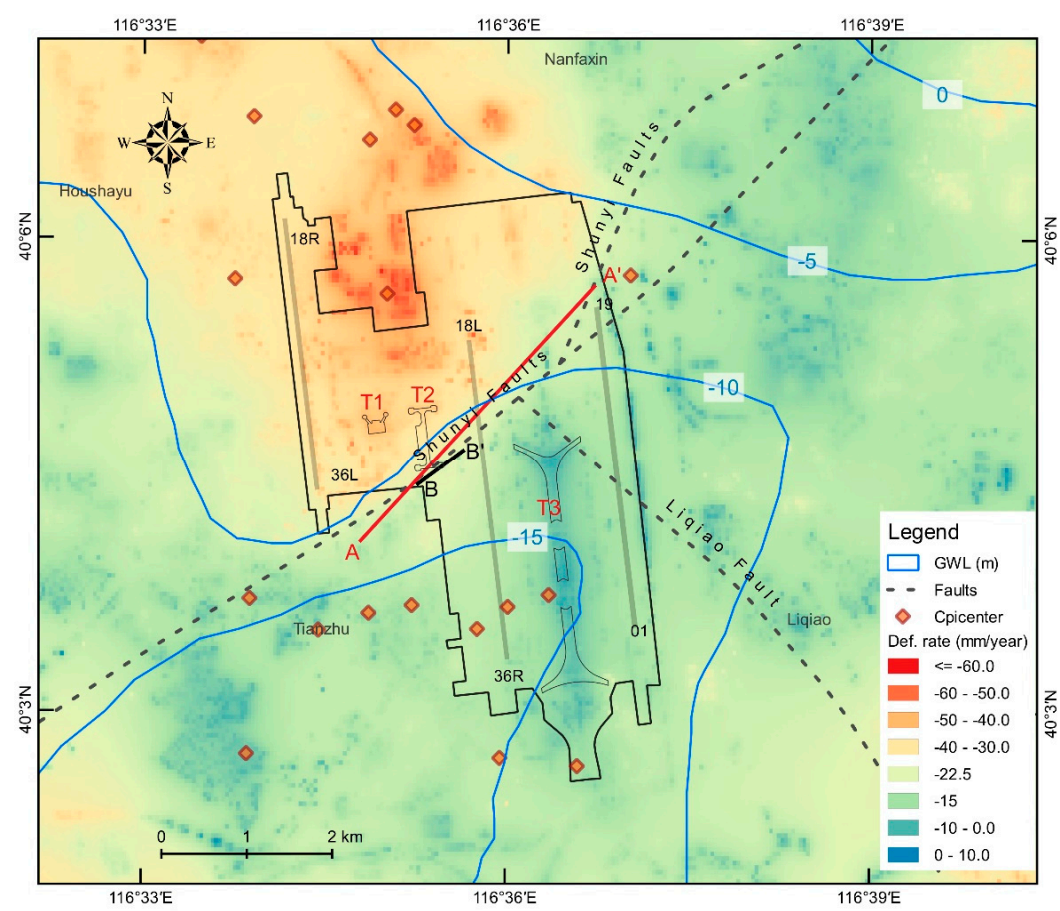

Figure 11. The distribution of the quaternary sedimentary types, groundwater level (GWL), and active faults, with interpolated deformation rate ( $\mathrm{mm} /$ year) in the study area. The black outlines show airport features, including terminals and airport boundaries. $\mathrm{A}-\mathrm{A}^{\prime}$ indicates the location of the ground fissures identified by InSAR measurements, while the B- $\mathrm{B}^{\prime}$ indicates the same from $\mathrm{Ma}$ and $\mathrm{Du}, 2017$ [48]. 
The borehole investigation showed that the vertical slip rate of the fracture was about $0.03 \mathrm{~mm} /$ year [49], far less than the deformation rate detected by InSAR, which indicates that the activity of Shunyi-liangxiang faults cannot fully explain recent ground fissure activity.

Generally, the ground fissures formed by uneven deformation caused by groundwater pumping will present the distribution characteristics related to the height of groundwater level (GWL); where GWLs are low, subsidence tends to be more severe. However, the distribution of GWL and land subsidence in the airport area did not show this correlation (as shown in Figure 11). It is preliminarily proved that the variation of GWL is not the main reason for the occurrence and development of the ground fissures.

In Shunyi County, the long-term overexploitation of the confined aquifer of $\sim 70-200 \mathrm{~m}$ underground resulted in the decline of the confined GWL, the decrease of pore water pressure and the increase of effective stress in the aquifer. Since the groundwater cannot be replenished in time, the skeleton of the aquifer was compressed and realized as land subsidence of the ground surface. The activity of ground fissures is related to the ground subsidence centers in Shunyi County. As mentioned in the second part of this study, the airport is located at the southern edge of the newly formed Nanfaxin sinking center and is adjacent to the Houshayu sinking center in the west, which is obviously affected by local uneven subsidence. The ground fissure is located at the southwest edge of the Houshayu-nanfaxin subsidence area and the relative average of subsidence on its both sides reaches $22.26 \mathrm{~cm}$, which is in line with the field investigation (a maximum displacement of $30 \mathrm{~cm}$ was obtained) implemented by CGS in late 2017; the period of ground fissure activity (identified by InSAR) coincides with the rapid development of land subsidence (since 1999). The normal faulting of the Shunyi-liangxiang fault in the early and middle quaternary period resulted in the development of thick, fine-grained, loose deposits with high compressibility in the lower side of the fault. In this case, the differential subsidence of the northern and southern sides of the fault resulted in the formation of the faulted zone in the airport area.

The overhaul of the 18L/36R runway lasted 28 days in April 2017, during which the number of daily flights decreased by more than 300 and the number of passengers sent was cut by about 15 percent. Furthermore, the airport had to change from a three-runway operation to a two-runway operation, which directly led to a decrease in runway capacity during rush hour, an extension of night flight time, and an increase in flight delay rate. It can be concluded that uneven ground subsidence and fractures seriously affected the normal operation of the airport.

The quaternary sediments at the location of the new ground fissure are about $400 \mathrm{~m}$ thick and the fractures penetrate from the bedrock to the ground surface; engineering measures barely eliminate the existence and development of ground fissures [48]. Uneven land subsidence and tectonic activities of Shunyi-liangxiang faults continuously sustain and enhance the ground fissures, which may induce geological hazards. Therefore, in order to ensure the safe operation of the airport, InSAR technology can be used for long-term and near-real-time monitoring of the airport area in cooperation with ground inspection. In this way, early warnings and engineering measures can be taken in time when abnormal conditions are found.

\section{Conclusions}

In this study, we performed an InSAR time series analysis for investigating the long-term uneven land subsidence and intensifying ground fissures since 2010 in Beijing Capital International Airport, China. An advanced InSAR technique, referred to as QPS-InSAR, was performed on TerraSAR-X/TanDem- $X$ data set, then spatial and time series measurements were obtained during the period of investigation from 2010 to 2017. The vertical displacements have been estimated to have a maximum value of $-1174.1 \mathrm{~mm}$, with a sinking rate of $152.9 \mathrm{~mm} /$ year. Comparison of the deformation rates from the InSAR and ground-leveling measurements shows the correlation coefficient is 0.96 with a standard deviation of $1.33 \mathrm{~mm} /$ year. After an integrated analysis of the distribution characteristics of land subsidence in Beijing Capital International Airport, previous research results, and geological 
data, we found and located an active ground fissure. Then, the main cause of the ground fissures was preliminarily discussed. We believe that the uneven land subsidence relating to the difference in sediment thickness on both sides of the Shunyi-liangxiang fault is the main factor of the formation of the new ground fissures, rather than the normal faulting itself and the variation of GWL. Due to the special environment of the airport where the ground fissures are located, we suggest the management of the airport combine spaceborne InSAR technology and ground surveys to monitor and forecast ground fissures, in order to provide technical guarantee for the safe operation of the airport. It can be concluded that InSAR technology can be used to identify and monitor geological processes such as land subsidence and ground fissure activities and can provide a scientific approach to better explore and study the cause and formation mechanisms of regional subsidence and ground fissures. Furthermore, it is worth remarking that this refreshes our understanding of the complex cause mechanisms of local land subsidence in the Beijing Plain area.

Author Contributions: Conceptualization, X.L.; data curation, L.G. and Z.N.; formal analysis, C.Z.; funding acquisition, M.G. and H.G.; investigation, G.D.; methodology, M.G.; project administration, H.G. and X.L.; software, C.Z. and M.S.; validation, B.C., L.G. and Z.C.; writing-original draft, M.G.; writing-review and editing, B.C. and Z.C.

Funding: This research was funded by the Beijing Postdoctoral Research Foundation, National Natural Science Foundation of China (No. 41771455/D010702, 4140010982/D010702), Beijing Municipal Natural Science Foundation (No. 8182013), Beijing Youth Top Talent Project, the program of Beijing Scholars, National "Double-Class" Construction of University Projects, and Natural Science Foundation of Tianjin City (No. 16JCZDJC40400).

Acknowledgments: The authors would like to thank the anonymous referees for their constructive comments and suggestions how to improve this manuscript. The provision of the QGIS and GMT (Generic Mapping Tools, referred to: http://gmt.soest.hawaii.edu/) for data processing and mapping are gratefully acknowledged.

Conflicts of Interest: The authors declare no conflict of interest.

\section{References}

1. Chen, M.; Tomás, R.; Li, Z.; Motagh, M.; Li, T.; Hu, L.; Gong, H.; Li, X.; Yu, J.; Gong, X. Imaging Land Subsidence Induced by Groundwater Extraction in Beijing (China) Using Satellite Radar Interferometry. Remote Sens. 2016, 8, 468. [CrossRef]

2. Zhang, T.; Shen, W.B.; Wu, W.; Zhang, B.; Pan, Y. Recent Surface Deformation in the Tianjin Area Revealed by Sentinel-1A Data. Remote Sens. 2019, 11, 130. [CrossRef]

3. Chen, J.; Wu, J.; Zhang, L.; Zou, J.; Liu, G.; Zhang, R.; Yu, B. Deformation Trend Extraction Based on Multi-Temporal InSAR in Shanghai. Remote Sens. 2013, 5, 1774-1786. [CrossRef]

4. Ishitsuka, K.; Tsuji, T.; Matsuoka, T.; Nishijima, J.; Fujimitsu, Y. Heterogeneous surface displacement pattern at the Hatchobaru geothermal field inferred from SAR interferometry time-series. Int. J. Appl. Earth Obs. Geoinf. 2016, 44, 95-103. [CrossRef]

5. Da Lio, C.; Tosi, L. Land subsidence in the Friuli Venezia Giulia coastal plain, Italy: 1992-2010 results from SAR-based interferometry. Sci. Total Environ. 2018, 633, 752-764. [CrossRef] [PubMed]

6. Castellazzi, P.; Arroyo-Domínguez, N.; Martel, R.; Calderhead, A.I.; Normand, J.C.L.; Gárfias, J.; Rivera, A. Land subsidence in major cities of Central Mexico: Interpreting InSAR-derived land subsidence mapping with hydrogeological data. Int. J. Appl. Earth Obs. Geoinf. 2016, 47, 102-111. [CrossRef]

7. Chaussard, E.; Wdowinski, S.; Cabral-Cano, E.; Amelung, F. Land subsidence in central Mexico detected by ALOS InSAR time-series. Remote Sens. Environ. 2014, 140, 94-106. [CrossRef]

8. Ng, A.H.M.; Ge, L.; Li, X.; Abidin, H.Z.; Andreas, H.; Zhang, K. Mapping land subsidence in Jakarta, Indonesia using persistent scatterer interferometry (PSI) technique with ALOS PALSAR. Int. J. Appl. Earth Obs. Geoinf. 2012, 18, 232-242. [CrossRef]

9. Chaussard, E.; Amelung, F.; Abidin, H.; Hong, S.H. Sinking cities in Indonesia: ALOS PALSAR detects rapid subsidence due to groundwater and gas extraction. Remote Sens. Environ. 2013, 128, 150-161. [CrossRef]

10. Chen, B.; Gong, H.; Lei, K.; Li, J.; Zhou, C.; Gao, M.; Guan, H.; Lv, W. Land subsidence lagging quantification in the main exploration aquifer layers in Beijing plain, China. Int. J. Appl. Earth Obs. Geoinf. 2019, 75, 54-67. [CrossRef] 
11. Jiang, L.; Lin, H. Integrated analysis of SAR interferometric and geological data for investigating long-term reclamation settlement of Chek Lap Kok Airport, Hong Kong. Eng. Geol. 2010, 110, 77-92. [CrossRef]

12. Wang, S.; Gong, H.; Du, Z.; Gu, Z. The Application of Persistent Scatterer Interferometry Technique to Beijing Capital International Airport. Bull. Surv. Mapp. 2012, 65-69.

13. Gao, M.; Gong, H.; Chen, B.; Zhou, C.; Chen, W.; Liang, Y.; Shi, M.; Si, Y. InSAR time-series investigation of long-term ground displacement at Beijing Capital International Airport, China. Tectonophysics 2016, 691, 271-281. [CrossRef]

14. He, Y.; Zhu, L.; Gong, H.; Wang, R. Analysis of land subsidence features based on TerraSAR images in Beijing-capital international airport. Sci. Surv. Mapp. 2016, 41, 14-18.

15. Yang, C.; Zhang, Q.; Zhao, C.; Wang, Q.; Ji, L. Monitoring land subsidence and fault deformation using the small baseline subset InSAR technique: A case study in the Datong Basin, China. J. Geodyn. 2014, 75, 34-40. [CrossRef]

16. Conway, B.D. Land subsidence and earth fissures in south-central and southern Arizona, USA. Hydrogeol. J. 2016, 24, 649-655. [CrossRef]

17. Zang, M.; Peng, J.; Qi, S. Earth fissures developed within collapsible loess area caused by groundwater uplift in Weihe watershed, northwestern China. J. Asian Earth Sci. 2019, 173, 364-373. [CrossRef]

18. Hu, J.; Li, Z.W.; Ding, X.L.; Zhu, J.J.; Zhang, L.; Sun, Q. 3D coseismic Displacement of 2010 Darfield, New Zealand earthquake estimated from multi-aperture InSAR and D-InSAR measurements. J. Geod. 2012, 86, 1029-1041. [CrossRef]

19. Fialko, Y.; Sandwell, D.; Simons, M.; Rosen, P. Three-dimensional deformation caused by the Bam, Iran, earthquake and the origin of shallow slip deficit. Nature 2005, 435, 295-299. [CrossRef]

20. Wang, T.; DeGrandpre, K.; Lu, Z.; Freymueller, J.T. Complex surface deformation of Akutan volcano, Alaska revealed from InSAR time series. Int. J. Appl. Earth Obs. Geoinf. 2018, 64, 171-180. [CrossRef]

21. Samsonov, S.V.; Feng, W.; Peltier, A.; Geirsson, H.; d'Oreye, N.; Tiampo, K.F. Multidimensional Small Baseline Subset (MSBAS) for volcano monitoring in two dimensions: Opportunities and challenges. Case study Piton de la Fournaise volcano. J. Volcanol. Geotherm. Res. 2017, 344, 121-138. [CrossRef]

22. Chen, Q.; Liu, X.; Zhang, Y.; Zhao, J.; Xu, Q.; Yang, Y.; Liu, G. A nonlinear inversion of InSAR-observed coseismic surface deformation for estimating variable fault dips in the 2008 Wenchuan earthquake. Int. J. Appl. Earth Obs. Geoinf. 2019, 76, 179-192. [CrossRef]

23. Jo, M.J.; Jung, H.S.; Yun, S.H. Retrieving Precise Three-Dimensional Deformation on the 2014 M6.0 South Napa Earthquake by Joint Inversion of Multi-Sensor SAR. Sci. Rep. 2017, 7, 5485. [CrossRef] [PubMed]

24. Zhao, F.; Mallorqui, J.; Iglesias, R.; Gili, J.; Corominas, J. Landslide Monitoring Using Multi-Temporal SAR Interferometry with Advanced Persistent Scatterers Identification Methods and Super High-Spatial Resolution TerraSAR-X Images. Remote Sens. 2018, 10, 921. [CrossRef]

25. Dong, J.; Zhang, L.; Tang, M.; Liao, M.; Xu, Q.; Gong, J.; Ao, M. Mapping landslide surface displacements with time series SAR interferometry by combining persistent and distributed scatterers: A case study of Jiaju landslide in Danba, China. Remote Sens. Environ. 2018, 205, 180-198. [CrossRef]

26. Zheng, M.; Deng, K.; Fan, H.; Du, S. Monitoring and Analysis of Surface Deformation in Mining Area Based on InSAR and GRACE. Remote Sens. 2018, 10, 1392. [CrossRef]

27. Liu, D.; Shao, Y.; Liu, Z.; Riedel, B.; Sowter, A.; Niemeier, W.; Bian, Z. Evaluation of InSAR and TomoSAR for Monitoring Deformations Caused by Mining in a Mountainous Area with High Resolution Satellite-Based SAR. Remote Sens. 2014, 6, 1476-1495. [CrossRef]

28. Liu, P.; Li, Q.; Li, Z.; Hoey, T.; Liu, Y.; Wang, C. Land Subsidence over Oilfields in the Yellow River Delta. Remote Sens. 2015, 7, 1540-1564. [CrossRef]

29. Cigna, F.; Osmanoğlu, B.; Cabral-Cano, E.; Dixon, T.H.; Ávila-Olivera, J.A.; Garduño-Monroy, V.H.; DeMets, C.; Wdowinski, S. Monitoring land subsidence and its induced geological hazard with Synthetic Aperture Radar Interferometry: A case study in Morelia, Mexico. Remote Sens. Environ. 2012, 117, 146-161. [CrossRef]

30. Chen, B.; Gong, H.; Li, X.; Lei, K.; Gao, M.; Zhou, C.; Ke, Y. Spatial-temporal evolution patterns of land subsidence with different situation of space utilization. Nat. Hazards 2015, 77, 1765-1783. [CrossRef]

31. Gao, M.; Gong, H.; Chen, B.; Li, X.; Zhou, C.; Shi, M.; Si, Y.; Chen, Z.; Duan, G. Regional Land Subsidence Analysis in Eastern Beijing Plain by InSAR Time Series and Wavelet Transforms. Remote Sens. 2018, 10, 365. [CrossRef] 
32. Guo, L.; Gong, H.; Zhu, F.; Zhu, L.; Zhang, Z.; Zhou, C.; Gao, M.; Sun, Y. Analysis of the Spatiotemporal Variation in Land Subsidence on the Beijing Plain, China. Remote Sens. 2019, 11, 1170. [CrossRef]

33. Ma, T.; Du, Y.; Ma, R.; Xiao, C.; Liu, Y. Review: Water-rock interactions and related eco-environmental effects in typical land subsidence zones of China. Hydrogeol. J. 2018, 26, 1339-1349. [CrossRef]

34. Brunori, C.; Bignami, C.; Albano, M.; Zucca, F.; Samsonov, S.; Groppelli, G.; Norini, G.; Saroli, M.; Stramondo, S. Land subsidence, Ground Fissures and Buried Faults: InSAR Monitoring of Ciudad Guzmán (Jalisco, Mexico). Remote Sens. 2015, 7, 8610-8630. [CrossRef]

35. Yang, C.; Lu, Z.; Zhang, Q.; Zhao, C.; Peng, J.; Ji, L. Deformation at longyao ground fissure and its surroundings, north China plain, revealed by ALOS PALSAR PS-InSAR. Int. J. Appl. Earth Obs. Geoinf. 2018, 67, 1-9. [CrossRef]

36. Hanssen, R.F. Radar Interferometry: Data Interpretation and Error Analysis; Springer: Berlin, Germany, 2001; ISBN 978-0-306-47633-4.

37. Ferretti, A.; Prati, C.; Rocca, F. Permanent Scatterers in SAR Interferometry. IEEE Trans. Geosci. Remote Sens. 2001, 39, 13. [CrossRef]

38. Ferretti, A.; Prati, C.; Rocca, F. Analysis of Permanent Scatterers in SAR interferometry. In Proceedings of the IGARSS 2000 IEEE 2000 International Geoscience and Remote Sensing Symposium: Taking the Pulse of the Planet: The Role of Remote Sensing in Managing the Environment, Proceedings (Cat. No.00CH37120), Honolulu, HI, USA, 24-28 July 2000; Volume 2, pp. 761-763.

39. Ferretti, A.; Savio, G.; Barzaghi, R.; Borghi, A.; Musazzi, S.; Novali, F.; Prati, C.; Rocca, F. Submillimeter Accuracy of InSAR Time Series: Experimental Validation. IEEE Trans. Geosci. Remote Sens. 2007, 45, 1142-1153. [CrossRef]

40. Crosetto, M.; Monserrat, O.; Cuevas-González, M.; Devanthéry, N.; Crippa, B. Persistent Scatterer Interferometry: A review. ISPRS J. Photogramm. Remote Sens. 2016, 115, 78-89. [CrossRef]

41. Perissin, D.; Wang, T. Repeat-Pass SAR Interferometry with Partially Coherent Targets. IEEE Trans. Geosci. Remote Sens. 2012, 50, 271-280. [CrossRef]

42. Zhou, C.; Gong, H.; Chen, B.; Li, X.; Li, J.; Wang, X.; Gao, M.; Si, Y.; Guo, L.; Shi, M.; et al. Quantifying the contribution of multiple factors to land subsidence in the Beijing Plain, China with machine learning technology. Geomorphology 2019, 335, 48-61. [CrossRef]

43. Tao, L.; Zhang, H.; Wang, C.; Tang, Y. Ground Deformation Retrieval Using Quasi Coherent Targets DInSAR, With Application to Suburban Area of Tianjin, China. IEEE J. Sel. Top. Appl. Earth Obs. Remote Sens. 2012, 5, 867-873. [CrossRef]

44. Perissin, D.; Wang, T. Time-Series InSAR Applications Over Urban Areas in China. IEEE J. Sel. Top. Appl. Earth Obs. Remote Sens. 2011, 4, 92-100. [CrossRef]

45. Xie, J.; Yang, G.; Bo, W. Study on the regional deformation field and strong earthquake risk of Beijing Area in the near future. North China Earthq. Sci. 2002, 20, 1-9.

46. Guo, L.; Bo, W.; Yang, G. Characteristics of current deformation of fault belts in north china. Crustal Deform. Earthq. 2003, 29-36.

47. Chen, B.; Gong, H.; Li, X.; Lei, K.; Zhu, L.; Gao, M.; Zhou, C. Characterization and causes of land subsidence in Beijing, China. Int. J. Remote Sens. 2017, 38, 808-826. [CrossRef]

48. Ma, W.; Du, M. Cause and preventions of the ground fissures in Beijing airport. J. Eng. Geol. 2017, $295-300$.

49. Zhang, S.; Nie, G.; Liu, X.; Ren, J.; Liu, G. Quaternary Activities of Northern Segment of the Shunyi-Liangxiang Fault. Earthq. Res. China 2005, 21, 84-92.

(C) 2019 by the authors. Licensee MDPI, Basel, Switzerland. This article is an open access article distributed under the terms and conditions of the Creative Commons Attribution (CC BY) license (http://creativecommons.org/licenses/by/4.0/). 